\title{
Competition between cheatgrass and bluebunch wheatgrass is altered by temperature, resource availability, and atmospheric $\mathrm{CO}_{2}$ concentration
}

\author{
Christian D. Larson ${ }^{1} \cdot$ Erik A. Lehnhoff ${ }^{2} \cdot$ Chance Noffsinger $^{1} \cdot$ Lisa J. Rew ${ }^{1}$
}

Received: 2 February 2017 / Accepted: 13 December 2017 / Published online: 22 December 2017

(c) The Author(s) 2017. This article is an open access publication

\begin{abstract}
Global change drivers (elevated atmospheric $\mathrm{CO}_{2}$, rising surface temperatures, and changes in resource availability) have significant consequences for global plant communities. In the northern sagebrush steppe of North America, the invasive annual grass Bromus tectorum (cheatgrass) is expected to benefit from projected warmer and drier conditions, as well as increased $\mathrm{CO}_{2}$ and nutrient availability. In growth chambers, we addressed this expectation using two replacement series experiments designed to test competition between B. tectorum and the native perennial bunchgrass Pseudoroegneria spicata. In the first experiment, we tested the effects of elevated temperature, decreased water and increased nutrient availability, on competition between the two species. In the second, we tested the effects of elevated atmospheric $\mathrm{CO}_{2}$ and decreased water availability on the competitive dynamic. In both experiments, under all conditions, $P$. spicata suppressed B. tectorum, though, in experiment one, warmer and drier conditions and elevated nutrient availability increased $B$. tectorum's competitiveness. In experiment two, when grown in monoculture, both species responded positively to elevated $\mathrm{CO}_{2}$. However, when grown in competition, elevated $\mathrm{CO}_{2}$ increased $P$. spicata's suppressive effect, and the combination of dry soil conditions and elevated $\mathrm{CO}_{2}$ enhanced this effect. Our findings demonstrate that $B$. tectorum competitiveness with $P$. spicata responds differently to global change drivers; thus, future conditions are unlikely to facilitate $B$. tectorum invasion into established $P$. spicata communities of the northern sagebrush steppe. However, disturbance (e.g., fire) to these communities, and the associated increase in soil nutrients, elevates the risk of $B$. tectorum invasion.
\end{abstract}

Keywords Bromus tectorum $\cdot$ Climate change $\cdot$ Plant invasion $\cdot$ Pseudoroegneria spicata $\cdot$ Replacement series design

Communicated by Yu-Long Feng.

Electronic supplementary material The online version of this article (https://doi.org/10.1007/s00442-017-4046-6) contains supplementary material, which is available to authorized users.

Christian D. Larson

utah131@gmail.com

Erik A. Lehnhoff

lehnhoff@nmsu.edu

Chance Noffsinger

chancenoffsinger@yahoo.com

Lisa J. Rew

lrew@montana.edu

1 Weed and Invasive Plant Ecology and Management Group, Land Resources and Environmental Science Department, Montana State University, Bozeman, MT 59717, USA

2 Entomology, Plant Pathology and Weed Science, New Mexico State University, Las Cruces, NM 88003, USA

\section{Introduction}

Atmospheric $\mathrm{CO}_{2}$ concentrations have increased at an unprecedented rate since the beginning of the industrial era (IPCC 2013). It is projected that the 2015-2016 atmospheric $\mathrm{CO}_{2}$ concentration growth rate will be highest on record and concentrations will surpass and remain above $400 \mathrm{ppm}$ for the entire year (Betts et al. 2016). The increase in atmospheric $\mathrm{CO}_{2}$ has altered many components of the Earth's climate, including surface temperatures and precipitation patterns (IPCC 2013). As plant growth is directly affected by temperature, precipitation (Woodward and Williams 1987) and atmospheric $\mathrm{CO}_{2}$ concentrations (Bazzaz 1990), these changes have consequences for global plant communities (Shaver et al. 2000; Cramer et al. 2001; Walther et al. 2002; Parmesan and Yohe 2003; Chen et al. 2011).

Elevated atmospheric $\mathrm{CO}_{2}$ has long been used to stimulate plant production; however, plant attributes shape individual 
and group responses (Bazzaz 1990). Elevated $\mathrm{CO}_{2}$ favors species with intrinsically higher growth rates because they have a higher maximum rate of photosynthesis and can more fully utilize the elevated resource level (Poorter and Navas 2003). Non-native invasive plant species often have high relative growth rates; therefore, it is expected they will benefit from elevated $\mathrm{CO}_{2}$ (Dukes and Mooney 1999; Weltzin et al. 2003; Moore 2004; Sorte et al. 2013). Consistent with this expectation, studies have found that non-native species demonstrate greater responses to elevated $\mathrm{CO}_{2}$ than native species (Ziska and George 2004), and elevated $\mathrm{CO}_{2}$ makes them more competitive with native species when grown together (Ziska and George 2004; Manea and Leishman 2011). The presence, density, and identity of competitors influence non-native responses to elevated $\mathrm{CO}_{2}$ (Bazzaz et al. 1992; Wayne et al. 1999; Manea and Leishman 2011). For example, the non-native species Centaurea solstitialis and Chenopodium album responded positively to elevated $\mathrm{CO}_{2}$ concentrations when grown in monoculture, but failed to respond significantly when grown in competitive settings (Taylor and Potvin 1997; Dukes 2002). Resource levels also affect plant responses to elevated $\mathrm{CO}_{2}$ (Bazzaz 1990). For example, by reducing stomatal density and conductance and increasing plant water use efficiency (Bazzaz 1990; Polley 1997; Morgan et al. 2004), elevated $\mathrm{CO}_{2}$ can mitigate the negative effects of warming and drying on plant growth (Dermody et al. 2007). Conversely, in a California grassland community, the invasive annual grass Bromus rubens responded positively to elevated $\mathrm{CO}_{2}$ during wet years and negatively in dry years (Smith et al. 2014). Dukes (2000) concluded that non-native plant responses to elevated $\mathrm{CO}_{2}$ are context dependent, influenced by ecosystem attributes, especially water availability and species identity.

Global vegetation models and recent studies predict changes to both temperature and precipitation regimes will significantly affect plant communities (Cramer et al. 2001; Lenoir and Svenning 2015), including the spread and success of non-native invasive plant species (Milchunas and Lauenroth 1995; Weltzin et al. 2003; Everard et al. 2010; Dukes et al. 2011; Hoeppner and Dukes 2012; Wu et al. 2016). Results from both observational and experimental studies are consistent with this expectation. For example, since 1900 , frost-free days in southern Switzerland have decreased while exotic species richness has increased (Walther et al. 2002). Likewise, an observed increase in minimum temperatures over a 23-year period at a Colorado shortgrass-steppe site were associated with reduced net primary production of the dominant grass species and increased exotic forb density (Alward et al. 1999). Similarly, drought is believed to be a significant contributor to the replacement of a California perennial bunchgrass ecosystem by an invasive annual grass ecosystem (Suttle and Thomsen 2007; Everard et al. 2010). Furthermore, a study in a Colorado shortgrass-steppe community found that experimentally elevated winter precipitation and decreased summer precipitation positively affected non-native invasive grass abundance and negatively affected native grass cover (Prevéy and Seastedt 2014). A recent study using a de Wit replacement series design with a native and non-native species found warming reduced native biomass and relative yield, especially at higher densities of the non-native species, and increased non-native biomass (Wu et al. 2016).

Recent bioclimatic envelope models indicate that the spatial extent of the invasive annual grass Bromus tectorum (cheatgrass) and its ecosystem dominance is likely to shift under future climate conditions (Bradley 2009; Bradley et al. 2016). Bromus tectorum is common throughout the western USA and has formed monoculture communities in the Columbia Basin, Great Basin, and Colorado Plateau regions (Mack 1981; Knapp 1996). Disturbance (fire and grazing) of native perennial communities facilitated its early establishment and subsequent invasion (Mack 1981; D’Antonio and Vitousek 1992). In western USA, wildfire frequency is correlated with warmer and drier conditions and is predicted to increase under future climate scenarios (Westerling et al. 2006, 2011). Fire increases soil nutrient levels (Hobbs and Huenneke 1992 and references therein; Blank et al. 2007), which is associated with increased B. tectorum growth and believed to contribute to $B$. tectorum's success (D'Antonio and Vitousek 1992; Vasquez et al. 2008; He et al. 2011; Orloff et al. 2013). The increase in fire frequency and the resulting change in soil nutrients create conditions which may facilitate the spread of B. tectorum (Chambers and Pellant 2008).

While elevated nutrient levels may contribute to $B$. tectorum's success, the presence of intact native perennial grass communities is the most important biotic factor limiting the spatial extent of the invasion (Brummer et al. 2016). Unfortunately, native community resilience to disturbance and resistance to $B$. tectorum invasion decreases along a climate gradient, being high in cool and moist systems and low in warm and dry systems (Chambers et al. 2007, 2014; Dodson and Root 2015). Furthermore, observational and experimental studies throughout the western USA have demonstrated that $B$. tectorum growth, cover, and abundance are associated with and respond positively to elevated temperatures and precipitation changes (Chambers et al. 2007; Compagnoni and Adler 2014a, b; Prevéy and Seastedt 2015; Blumenthal et al. 2016; Brummer et al. 2016). Similarly, single factor $\mathrm{CO}_{2}$ monoculture studies indicate that $B$. tectorum responds positively to elevated $\mathrm{CO}_{2}$ concentrations (Smith et al. 1987; Poorter 1993; Ziska et al. 2005). However, these results may not conclusively represent how $B$. tectorum will respond to future $\mathrm{CO}_{2}$ levels because $B$. tectorum has responded neutrally to elevated $\mathrm{CO}_{2}$ concentrations when evaluated in a community setting (Blumenthal et al. 2016). 
Bromus tectorum growth and invasive success is associated with temperature, soil moisture, available nutrients, and competition with native perennial grasses; however, no research has studied the combination of all these factors in a controlled setting. Therefore, the first goal of our study was to determine if the competitive dynamic between $B$. tectorum and a recently established native perennial bunchgrass, Pseudoroegneria spicata, is responsive to changes in these experimental treatments. Pseudoroegneria spicata (bluebunch wheatgrass) is a desirable native perennial bunchgrass, common throughout western USA sagebrush-grassland communities and, when undisturbed, $P$. spicata and native grass communities limit $B$. tectorum growth and its landscape presence (Orloff et al. 2013; Brummer et al. 2016). Given the general paucity of literature on how $B$. tectorum responds to elevated $\mathrm{CO}_{2}$ concentrations (three monoculture studies and one community study), our second goal was to determine if competition between $B$. tectorum and recently established $P$. spicata individuals is responsive to elevated $\mathrm{CO}_{2}$ concentrations and if decreased water availability impacts this response. We hypothesized that in both experiments, increasing proportional density of recently established $P$. spicata individuals would have the greatest limiting effect on the establishing $B$. tectorum individuals. Secondly, we hypothesized that decreased water availability and increased temperature would favor B. tectorum, and that increased nutrient availability would further heighten B. tectorum competitiveness. Finally, we hypothesized that elevated $\mathrm{CO}_{2}$ concentrations and the combination of elevated $\mathrm{CO}_{2}$ and decreased soil water availability would increase $B$. tectorum's competitiveness with established $P$. spicata individuals.

\section{Methods}

\section{Experimental design}

Experiment 1: decreased water, increased temperature, and increased nutrient availability This experiment was a full factorial across two water treatments, two temperature treatments, and two nutrient treatments (Online Resource 1). The treatments were replicated twice in five density combinations of $B$. tectorum seedlings and recently established $P$. spicata individuals and we performed two trials, providing four replicates of each density-treatment combination. Both trials were performed in growth chambers at the Plant Growth Center, Montana State University (MSU), Bozeman, MT (April-June and July-September, 2014).

Our temperature and water treatments were designed to represent the Southwest Montana climate in spring when plants are actively growing. Southwest Montana has cold, dry winters (November-March) and warm, dry summers
(July-August) and receives a large percentage of its precipitation (46\%) in the spring (April-June). For the temperature treatment, we used the mean maximum temperature and day length in June: the low temperature chamber [Temp. (-)] was $23.3{ }^{\circ} \mathrm{C}$ for the daylight period ( $14 \mathrm{~h}$ of 100 micromoles of PAR) and $6{ }^{\circ} \mathrm{C}$ for the night period $(10 \mathrm{~h})$; the elevated temperature chamber [Temp. (+)] was two degrees higher for both the day and night periods $\left(25.3\right.$ and $8{ }^{\circ} \mathrm{C}$, respectively). To control for chamber effect, growth chamber temperatures were switched every 2 weeks and the plants were moved. The water treatment was designed to simulate ambient June precipitation $(77 \mathrm{~mm})$ [Water $(+)]$ and a reduction of this amount by $50 \%$ [Water $(-)$ ]. For the elevated nutrient treatment $(\mathrm{NPK}+), 173,75.50$, and $17.30 \mathrm{mg}$ of slow release $\mathrm{N}, \mathrm{P}$, and $\mathrm{K}$, was added, respectively.

The total target density for each pot was 50 plants pot $^{-1}$ (988 plants $\mathrm{m}^{-2}$ ). The five density combinations of B. tectorum and $P$. spicata individuals were: 50:0, 37:13, 25:25, 13:37, 0:50 plants pot $^{-1}$ (representing 988, 731, 494, 256 and 0 B. tectorum plants $\mathrm{m}^{-2}$, respectively). These densities were based on $B$. tectorum densities found locally at the Montana State University (MSU) Red Bluff Research Station near Norris, MT. Seeds were sown into circular pots (25.4 cm diameter) filled with equal parts of loam, sand, and organic matter. The soil was aerated and steam pasteurized at $70{ }^{\circ} \mathrm{C}$ for $60 \mathrm{~min}$. Seeds were randomly sown within a grid with $2 \mathrm{~cm}$ spacing and, to account for edge effects, no seeds were sown closer than $4 \mathrm{~cm}$ to the sides of the pot. To simulate $B$. tectorum invasion of a recently established $P$. spicata community, the $P$. spicata seeds were sown 1 month before B. tectorum. The P. spicata seeds were the 'Goldar' variety obtained from the USDA Natural Resources Conservation Service, Aberdeen Plant Materials Center (Aberdeen, ID). The B. tectorum seeds were hand collected at the MSU Red Bluff Research Station. After the $B$. tectorum seeds were sown into the established $P$. spicata, the pots were watered evenly to facilitate germination and moved immediately to the temperature-controlled chambers, where the water and nutrient treatments were subsequently implemented. As an annual, B. tectorum establishes readily from seed into more established bunch grass communities; therefore, we designed the experiment so that the treatments affected B. tectorum germination. At the termination of the experiment, the height of ten randomly selected individuals ( 5 of each species in mixed pots) was recorded, and the total aboveground biomass for each pot was clipped, dried, and weighed, by species. After B. tectorum was sown, trials 1 and 2 were conducted for 70 and 67 days, respectively.

Experiment 2: elevated atmospheric $\mathrm{CO}_{2}$ concentration and decreased water availability at an increased temperature Under the same temperature and daylight conditions as the high temperature treatment of the previous experiment (25.3 and $8{ }^{\circ} \mathrm{C}, 14 \mathrm{~h}$ days and $10 \mathrm{~h}$ nights), this experiment 
was full factorial across two atmospheric $\mathrm{CO}_{2}$ concentrations and two water treatment levels. $\mathrm{CO}_{2}$ concentrations were: ambient $\left[\mathrm{CO}_{2}(-) ; 400 \mathrm{ppm}\right]$ and elevated $\left[\mathrm{CO}_{2}(+)\right.$; $800 \mathrm{ppm}$ ]. Similar to the previous experiment, the water treatment represented average June precipitation [Water $(+)$ ] and a $50 \%$ reduction [Water $(-)$ ]. In this experiment, we used the same soil, seed, and seeding methods as we did in the first experiment. This experiment also utilized a replacement series design with five different density combinations of $B$. tectorum individuals and established $P$. spicata individuals. However, this experiment utilized smaller square pots $(11 \mathrm{~cm} \times 11 \mathrm{~cm})$ and the total target density for each pot was 12 plants $\operatorname{pot}^{-1}\left(1000\right.$ plants $\left.\mathrm{m}^{-2}\right)$. Thus, the five density combinations of $B$. tectorum individuals and $P$. spicata individuals were: 12:0, 9:3, 6:6, 3:9, 0:12 plants pot $^{-1}(1000$, 750, 500, 250, 0 B. tectorum plants $\mathrm{m}^{-2}$, respectively). There were six replicates of each density (5-level), $\mathrm{CO}_{2}$ (2-level), and water (2-level) treatment, resulting in a total of 120 pots per trial. Like the first experiment, we performed two trials of this experiment (January-April 2015 and May-August 2015). The trials were run for 69 and 54 days after B. tectorum was sown in the first and second trial, respectively. Upon the termination of the experiment, the final height was taken from all individuals in the pot and the aboveground biomass was clipped, dried, and weighed.

\section{Statistical analysis}

To evaluate the competition effects between $B$. tectorum $(B)$ and $P$. spicata $(P)$ under the different treatment conditions, we calculated relative yield (RY) using the proportion of the species in mixture $(P)$, mean species biomass of the species in mixture (mix), and mean species biomass in monoculture (mon), using the following formulae (Cousens and Neill 1993):

$\mathrm{RY}_{\mathrm{B}}=P_{\mathrm{B}} \times\left(B_{\text {mix }} / B_{\text {mon }}\right)$,

$\mathrm{RY}_{\mathrm{P}}=P_{\mathrm{P}} \times\left(P_{\text {mix }} / P_{\text {mon }}\right)$.

Relative yield indicates resource demands of the separate species and the shape of the curve indicates species interference (Burnett and Mealor 2015). If the species compete equally against one another, the RY should equal the expected proportion of the plants in the pot (Burnett and Mealor 2015). We also derived total relative yield (RYT), the sum of each species' relative yield in each pot (Weigelt and Jolliffe 2003). RYT below 1 likely indicates competitive interference (Burnett and Mealor 2015). RYT is often interpreted using diagrams and can reveal interference (in) equalities and can indicate the direction of the imbalances (Weigelt and Jolliffe 2003). Both RY and RYT use a constant derived from an unknown amount of intraspecific competition (Weigelt and Jolliffe 2003); therefore, we also calculated the specific proportion of the total biomass for each pot. Finally, we analyzed the effects of competition and the treatments on the mean final height and aboveground biomass of each species within each pot.

We analyzed the effects of competition and the treatments using linear mixed-effects models. All models were fit with the experimental treatments and the proportion of $P$. spicata in each pot as fixed effects and trial as a random effect. To satisfy model assumptions of normality and heteroscedasticity, the following data were transformed for the first experiment: $B$. tectorum relative yield and biomass were square root transformed, $P$. spicata relative yield was logit transformed, and the species proportion of the total biomass was logit transformed. In the second experiment, the following data were transformed: B. tectorum height and biomass were both log transformed, $B$. tectorum relative yield was logit transformed, $P$. spicata biomass and relative yield were square root transformed, RYT was also square root transformed, and the species proportion of the total biomass was logit transformed. The initial models included interactions and were reduced to the most parsimonious model with experimental treatments still included. The target proportions of each species were not always achieved; therefore, we calculated and used the actual proportion of $P$. spicata in each pot, creating a continuous variable that was used in the analysis and the graphics. The proportion of $P$. spicata within each pot was used as an explanatory variable for both $P$. spicata and B. tectorum, because it was established prior to $B$. tectorum and it better explained the variation the competitive pots than did the proportion of B. tectorum. The analyses were conducted using the statistical program R (version 3.2.2, R Development Core Team 2015). Linear mixed-effects models were constructed using the lme4 package (Bates et al. 2011) and the lmerTest package (Kuznetsova et al. 2014). Significant relationships between the treatment effects and the response variables were calculated at the $P<0.05$ level from T-statistics based on Satterthwaite's approximations of degrees of freedom for mixed-effects models (Kuznetsova et al. 2014).

\section{Results}

\section{Effects of competition, decreased water, elevated temperature, and increased nutrient availability}

Bromus tectorum relative yield responded positively to elevated temperature and increased nutrients $(P=0.038$ and $P=0.003$, respectively), demonstrated no response to water availability $(P=0.165)$, and negatively to the pot proportion of $P$. spicata $(P<0.001$; Table 1$)$. The decreased water and elevated temperature treatments negatively affected $P$. spicata relative yield ( $P<0.001$ and $P=0.029$, respectively). 
Table 1 Results of the linear mixed-effects models assessing the effects of experimental treatments on B. tectorum and $P$. spicata aboveground biomass $(\mathrm{g})$, height $(\mathrm{cm})$, and relative yield $(\mathrm{RY})$, for the first experiment

\begin{tabular}{|c|c|c|c|c|c|c|c|c|}
\hline \multicolumn{7}{|l|}{ Fixed effects } & \multirow{2}{*}{\multicolumn{2}{|c|}{$\frac{\text { Random effects }}{\text { Variance }}$}} \\
\hline \multirow[t]{2}{*}{ Response } & \multirow[t]{2}{*}{ Predictor } & \multirow[t]{2}{*}{ Est. } & \multirow[t]{2}{*}{ SE } & \multirow[t]{2}{*}{$d f$} & \multirow[t]{2}{*}{$t$ value } & \multirow[t]{2}{*}{$P(>)$} & & \\
\hline & & & & & & & Trial & Residual \\
\hline \multicolumn{9}{|l|}{ B. tectorum } \\
\hline \multirow[t]{6}{*}{ Biomass (g) } & Intercept & 1.72 & 0.15 & 1.31 & 11.39 & 0.029 & $0.038 \pm 0.20$ & $0.12 \pm 0.34$ \\
\hline & Water $(-)$ & -0.18 & 0.06 & 111.00 & -2.88 & 0.005 & & \\
\hline & Temp (+) & -0.04 & 0.06 & 111.03 & -0.67 & 0.505 & & \\
\hline & NPK (+) & 0.26 & 0.06 & 111.01 & 4.14 & $<0.001$ & & \\
\hline & P. spicata & -10.79 & 0.48 & 111.05 & -22.49 & $<0.001$ & & \\
\hline & Water $(-) \times P$. spicata & 1.96 & 0.68 & 111.00 & 2.86 & 0.005 & & \\
\hline \multirow[t]{5}{*}{ Height $(\mathrm{cm})$} & Intercept & 19.85 & 1.54 & 1.20 & 12.86 & 0.031 & $4.18 \pm 2.05$ & $8.22 \pm 2.87$ \\
\hline & Water $(-)$ & -3.50 & 0.56 & 100.00 & -6.27 & $<0.001$ & & \\
\hline & Temp (+) & -0.01 & 0.56 & 100.02 & -0.02 & 0.982 & & \\
\hline & NPK (+) & 2.01 & 0.56 & 100.01 & 3.60 & $<0.001$ & & \\
\hline & P. spicata & -40.24 & 2.96 & 100.44 & -13.58 & $<0.001$ & & \\
\hline \multirow[t]{6}{*}{ Relative yield (RY) } & Intercept & -3.30 & 0.32 & 1.30 & -10.20 & 0.033 & $0.17 \pm 0.42$ & $0.40 \pm 0.63$ \\
\hline & Water $(-)$ & -0.19 & 0.14 & 79.00 & 1.40 & 0.165 & & \\
\hline & Temp (+) & 0.29 & 0.14 & 79.04 & 2.11 & 0.038 & & \\
\hline & NPK (+) & 0.43 & 0.14 & 79.02 & 3.12 & 0.003 & & \\
\hline & P. spicata & -13.90 & 0.65 & 79.36 & -21.50 & $<0.001$ & & \\
\hline & P. spicata ${ }^{2}$ & -1.29 & 0.64 & 79.16 & -2.02 & 0.047 & & \\
\hline \multicolumn{9}{|l|}{ P. spicata } \\
\hline \multirow[t]{6}{*}{ Biomass (g) } & Intercept & 8.31 & 1.59 & 1.06 & 5.23 & 0.109 & $4.85 \pm 2.20$ & $2.36 \pm 1.54$ \\
\hline & Water $(-)$ & -2.50 & 0.4 & 111.00 & -6.30 & $<0.001$ & & \\
\hline & Temp (+) & -1.22 & 0.28 & 111.01 & -4.29 & $<0.001$ & & \\
\hline & NPK $(+)$ & 2.16 & 0.40 & 111.01 & 5.42 & $<0.001$ & & \\
\hline & P. spicata & 15.39 & 1.55 & 111.03 & 9.92 & $<0.001$ & & \\
\hline & Water $(-) \times$ NPK $(+)$ & -1.92 & 0.57 & 111.00 & -3.38 & 0.001 & & \\
\hline \multirow[t]{5}{*}{ Height (cm) } & Intercept & 34.84 & 0.63 & 102.00 & 55.15 & $<0.001$ & $0.00 \pm 0.00$ & $11.37 \pm 3.37$ \\
\hline & Water $(-)$ & -5.99 & 0.65 & 102.00 & -9.18 & $<0.001$ & & \\
\hline & Temp (+) & -2.21 & 0.65 & 102.00 & -3.39 & $<0.001$ & & \\
\hline & NPK $(+)$ & 1.10 & 0.65 & 102.00 & 1.69 & 0.094 & & \\
\hline & P. spicata & -13.48 & 3.37 & 102.00 & -4.00 & $<0.001$ & & \\
\hline \multirow[t]{7}{*}{ Relative yield (RY) } & Intercept & -0.22 & 0.09 & 79.00 & -2.41 & 0.018 & $0.00 \pm 0.00$ & $0.15 \pm 0.39$ \\
\hline & Water $(-)$ & -0.43 & 0.12 & 79.00 & -3.71 & $<0.001$ & & \\
\hline & Temp (+) & -0.26 & 0.12 & 79.00 & -2.22 & 0.029 & & \\
\hline & NPK $(+)$ & -0.03 & 0.08 & 79.00 & -0.38 & 0.702 & & \\
\hline & P. spicata & 9.73 & 0.39 & 79.00 & 25.15 & $<0.001$ & & \\
\hline & P. spicata ${ }^{2}$ & -0.82 & 0.39 & 79.00 & -2.11 & 0.038 & & \\
\hline & Water $(-) \times$ Temp $(+)$ & 0.36 & 0.17 & 79.00 & 2.13 & 0.036 & & \\
\hline
\end{tabular}

Experimental treatments were: competition with Pseudoroegneria spicata, decreased water availability, water (-), increased temperature, temp. $(+)$, and increased nutrient availability, NPK (+). Response variables were assessed in pots with $0.2 \mathrm{~m}^{-2}$ area. Random effects are the mean trial and residual variance and the associated standard deviation

However, there was an interaction between these variables $(P=0.036)$, indicating that the mean $P$. spicata relative yield in warm and dry conditions was greater than the mean in ambient and dry conditions. Pseudoroegneria spicata relative yield was unresponsive to the nutrient treatment
$(P=0.702)$ and responded positively to the proportion of $P$. spicata within the pot $(P<0.001$; Table 1$)$. RYT was significantly affected by proportion of $P$. spicata and was below 1, indicating interference between the two species $(P<0.001$; Fig. 1$)$. The decreased water treatment had a 
Fig. 1 The relative yield total (RYT) for a water treatments: ambient (dotted line, solid triangles) and decreased (solid line, solid circles); b nutrient treatments: ambient (black line, solid circles) and elevated (gray line, solid triangles). A mixedeffects model demonstrated that RYT responded negatively to water availability $(n=86$, $P=0.030$ ), but positively to elevated nutrient availability $(n=86, P=0.027)$ and pot proportion of Pseudoroegneria spicata $(n=86, P<0.001)$

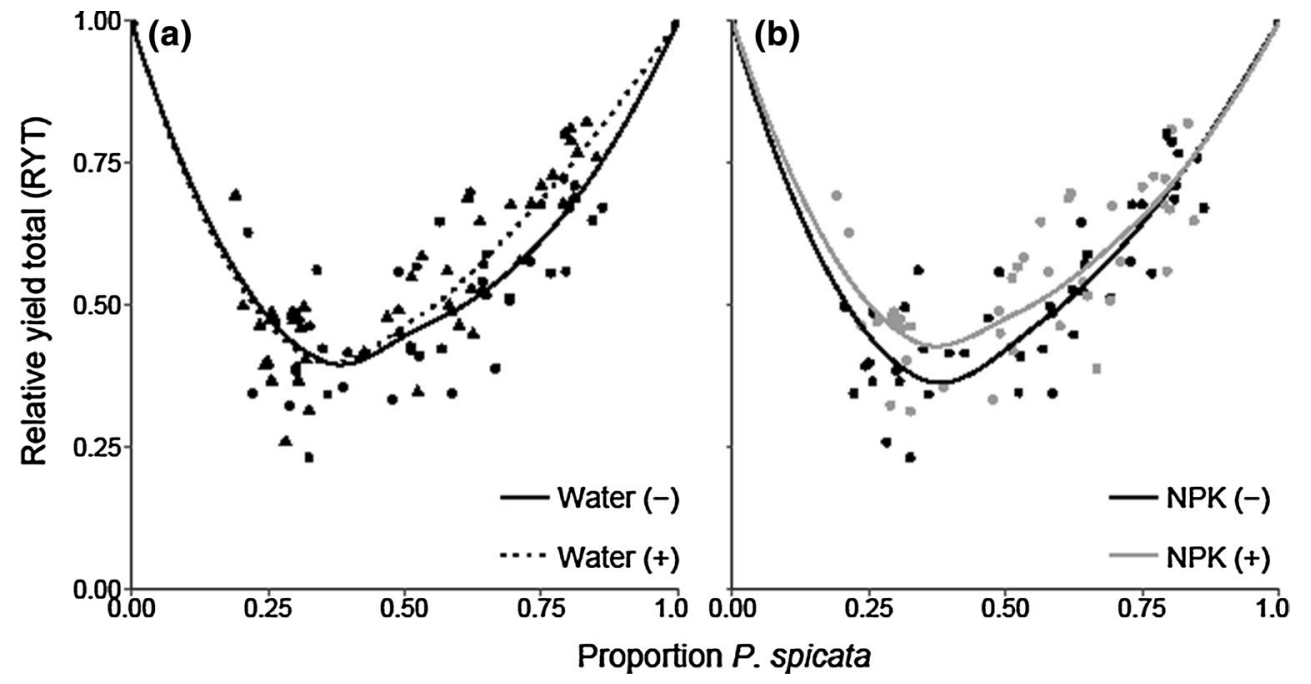

negative effect on RYT, indicating increased competitive interference between the two species ( $P=0.030$; Fig. 1a). RYT responded positively to the increased nutrient treatment, indicating that the nutrient treatment decreased competitive interference $(P=0.027$; Fig. 1 b; Table 2$)$.

Bromus tectorum aboveground biomass responded negatively to the interspecific competition with the established $P$. spicata individuals $(P<0.001)$, and decreased water availability $(P=0.005)$, while it responded positively to nutrient addition $(P<0.001$; Table 1$)$. There was an interaction between the interspecific competition and water availability $(P=0.005$; Table 1$)$; the suppressive effect of $P$. spicata on $B$. tectorum aboveground biomass was greater at high $P$. spicata proportions in the watered treatment than in the decreased water treatment. Bromus tectorum height responded negatively to interspecific competition $(P<0.001)$ and decreased water availability $(P<0.001)$, while it responded positively to increased nutrient availability ( $P<0.001$; Fig. 2a; Table 1$)$. Neither B. tectorum biomass nor height responded to elevated temperature (Table 1).

Pseudoroegneria spicata aboveground biomass responded negatively to decreased water availability $(P<0.001)$ and elevated temperature $(P<0.001)$, but responded positively to nutrient availability $(P<0.001)$ and increased $P$. spicata proportion $(P<0.001)$. There was an interaction between the water treatment and the nutrient treatment $(P=0.001)$; in the watered treatment, added nutrients had a positive effect while in the ambient water treatment added nutrients had no effect. $P$. spicata height responded negatively to decreased water availability $(P<0.001)$, increased temperature $(P<0.001)$, and when $P$. spicata proportion increased $(P<0.001$; Fig. 2 b), but did not demonstrate a response to the increased nutrient availability treatment $(P=0.094$; Table 1$)$.

Bromus tectorum proportion of the total pot biomass responded positively to decreased water availability
$(P=0.009)$ and increased nutrient availability $(P=0.003)$, and there was minimal evidence that increased temperature also had a positive effect ( $P=0.071$; Table 2$)$. The proportion of $P$. spicata within the pot negatively affected the pot biomass $B$. tectorum $(P<0.001$; Table 2$)$.

\section{Effects of competition, elevated atmospheric $\mathrm{CO}_{2}$, and decreased water availability under an increased temperature}

Bromus tectorum relative yield responded negatively to elevated $\mathrm{CO}_{2}$ and the pot proportion of $P$. spicata $(P<0.001$ and $P<0.001$, respectively; Fig. 3), but demonstrated no response to the decreased water treatment $(P=0.339$; Table 3$)$. In contrast, $P$. spicata relative yield demonstrated no response to the elevated $\mathrm{CO}_{2}$ treatment $(P=0.233)$, a negative response to the decreased water treatment $(P=0.001)$, and there was an interaction between the two factors $(P<0.001$; Fig. 4 ; Table 3$)$ : $P$. spicata relative yield demonstrated no response to elevated $\mathrm{CO}_{2}$ in the ambient water treatment (Fig. 4a), but when water availability was reduced $P$. spicata relative yield responded positively to elevated $\mathrm{CO}_{2}$ (Fig. 4b). Pseudoroegneria spicata relative yield responded positively when its pot proportion increased $\left(P<0.001\right.$; Fig. 4; Table 3). Neither the elevated $\mathrm{CO}_{2}$ treatment nor the decreased water treatment affected the RYT ( $P=0.259$ and $P=0.571$, respectively; Table 2$)$, while the proportion of $P$. spicata did affect the RYT, which was below 1 indicating competitive interference between the species $(P<0.001$; Table 2$)$.

Bromus tectorum biomass and height responded negatively to both interspecific competition with $P$. spicata ( $P<0.001$ and $P<0.001$, respectively) and the elevated $\mathrm{CO}_{2}$ treatment $(P=0.012, P=0.050$, respectively; Table 3$)$. In addition, decreased water negatively affected $B$. tectorum biomass $(P=0.014)$, but did not affect its height $(P=0.086$; 
Table 2 Results of the best linear mixed-effects models assessing the impact of the experimental treatments on Bromus tectorum and Pseudoroegneria spicata proportion of the total pot biomass (prop. biomass) and relative yield total (RYT) for both experiments

\begin{tabular}{|c|c|c|c|c|c|c|c|c|}
\hline \multicolumn{7}{|l|}{ Fixed effects } & \multirow{2}{*}{\multicolumn{2}{|c|}{$\frac{\text { Random effects }}{\text { Variance }}$}} \\
\hline \multirow[t]{2}{*}{ Response } & \multirow[t]{2}{*}{ Predictor } & \multirow[t]{2}{*}{ Est. } & \multirow[t]{2}{*}{ SE } & \multirow[t]{2}{*}{$d f$} & \multirow[t]{2}{*}{$t$ value } & \multirow[t]{2}{*}{$P(>)$} & & \\
\hline & & & & & & & Trial & Residual \\
\hline \multicolumn{9}{|l|}{ Experiment 1} \\
\hline \multirow[t]{5}{*}{ Prop. biomass } & Intercept & -2.18 & 0.60 & 1.09 & -3.61 & 0.155 & $0.68 \pm 0.83$ & $0.49 \pm 0.70$ \\
\hline & Water $(-)$ & 0.40 & 0.15 & 80.00 & 2.68 & 0.009 & & \\
\hline & Temp (+) & 0.28 & 0.15 & 80.01 & 1.83 & 0.071 & & \\
\hline & NPK $(+)$ & 0.46 & 0.15 & 80.01 & 3.02 & 0.003 & & \\
\hline & P. spicata & -10.23 & 0.72 & 80.12 & -14.30 & $<0.001$ & & \\
\hline \multirow[t]{6}{*}{ Relative yield total (RYT) } & Intercept & 0.51 & 0.02 & 2.89 & 22.24 & $<0.001$ & $<0.001 \pm 0.02$ & $0.007 \pm 0.08$ \\
\hline & Water $(-)$ & -0.04 & 0.02 & 79.00 & -2.21 & 0.030 & & \\
\hline & Temp (+) & 0.03 & 0.02 & 79.20 & 1.74 & 0.086 & & \\
\hline & NPK (+) & 0.04 & 0.02 & 79.08 & 2.26 & 0.027 & & \\
\hline & P. spicata & 0.96 & 0.08 & 80.00 & 11.43 & $<0.001$ & & \\
\hline & P. spicata ${ }^{2}$ & 0.46 & 0.08 & 79.61 & 5.59 & $<0.001$ & & \\
\hline \multicolumn{9}{|l|}{ Experiment 2} \\
\hline \multirow[t]{7}{*}{ Prop. biomass } & Intercept & -1.23 & 0.32 & 1.46 & -3.87 & 0.098 & $0.15 \pm 0.39$ & $1.15 \pm 1.07$ \\
\hline & $\mathrm{CO}_{2}(+)$ & -1.66 & 0.19 & 131.00 & -8.82 & $<0.001$ & & \\
\hline & Water $(-)$ & -0.15 & 0.18 & 131.00 & -0.80 & 0.428 & & \\
\hline & P. spicata & -11.29 & 1.74 & 131.61 & -6.50 & $<0.001$ & & \\
\hline & P. spicata ${ }^{2}$ & 5.69 & 1.84 & 131.06 & -3.10 & 0.002 & & \\
\hline & P. spicata $\times \mathrm{CO}_{2}$ & 3.81 & 2.42 & 131.33 & 1.57 & 0.118 & & \\
\hline & P. spicata ${ }^{2} \times \mathrm{CO}_{2}$ & -6.89 & 2.38 & 131.12 & -2.89 & 0.004 & & \\
\hline \multirow[t]{4}{*}{ Relative yield total (RYT) } & Intercept & 0.68 & 0.05 & 1.19 & 13.58 & 0.030 & $0.004 \pm 0.07$ & $0.01 \pm 0.12$ \\
\hline & $\mathrm{CO}_{2}(+)$ & -0.02 & 0.02 & 134.00 & -1.13 & 0.259 & & \\
\hline & Water $(-)$ & -0.01 & 0.02 & 134.00 & -0.57 & 0.571 & & \\
\hline & P. spicata & 0.98 & 0.12 & 134.14 & 7.94 & $<0.001$ & & \\
\hline
\end{tabular}

The experimental treatments assessed for experiment one: $P$. spicata pot density, decreased water availability, water (-), increased temperature, temp. (+), and increased nutrient availability, NPK (+). The experimental treatments assessed for experiment two: $P$. spicata pot density, decreased water availability, water $(-)$, and elevated atmospheric $\mathrm{CO}_{2}$ concentration, $\mathrm{CO}_{2}(+)$. The random effects are the mean trial and residual variance and the associated standard deviation

Table 3). An interaction between increasing $P$. spicata pot density and the $\mathrm{CO}_{2}$ treatment affected both $B$. tectorum aboveground biomass and height $(P<0.001$ and $P=0.002$, respectively; Table 3); under elevated $\mathrm{CO}_{2}$, the effects of increasing $P$. spicata pot density (greater interspecific competition) were magnified.

Pseudoroegneria spicata biomass and height responded positively to elevated $\mathrm{CO}_{2}(P<0.001$ and $P<0.001$, respectively; Table 3). However, as the proportion of $P$. spicata increased, only its biomass responded positively $(P<0.001$; Table 3). Both $P$. spicata biomass and height responded negatively to the decreased water treatment $(P<0.001$, $P<0.001$, respectively; Table 3 ). For both response variables, there was an interaction between $P$. spicata density and $\mathrm{CO}_{2}(P<0.001, P<0.001$, respectively; Table 3$)$ : as $P$. spicata density increased, the mean biomass in the ambient $\mathrm{CO}_{2}$ treatment increased at a greater rate than did the mean biomass within the elevated $\mathrm{CO}_{2}$ treatment; and, as $P$. spicata density increased, its mean height actually decreased in the elevated $\mathrm{CO}_{2}$ treatment, while its mean height in the ambient $\mathrm{CO}_{2}$ treatment was unaffected by the increasing density.

Elevated $\mathrm{CO}_{2}$ positively affected the biomass and height of both species when they were grown in monoculture. In monoculture, B. tectorum mean biomass in the elevated $\mathrm{CO}_{2}$ treatment $(8.49 \mathrm{~g})$ was greater than its mean biomass in ambient $\mathrm{CO}_{2}(5.09 \mathrm{~g} ; P<0.001, t$ statistic $=12.56$, $d f=43$ ). Likewise, the mean height of $B$. tectorum grown in monoculture under elevated $\mathrm{CO}_{2}(25.66 \mathrm{~cm})$ was taller than its mean height in ambient $\mathrm{CO}_{2}(21.34 \mathrm{~cm} ; P<0.001$, $t$ statistic $=6.19, d f=43)$. When grown in monoculture, $P$. spicata mean biomass in the elevated $\mathrm{CO}_{2}$ treatment $(4.55 \mathrm{~g}$ ) was greater than its mean biomass in ambient $\mathrm{CO}_{2}(2.88 \mathrm{~g}$; $P<0.001, t$ statistic $=5.22, d f=43)$. Similarly, the mean 


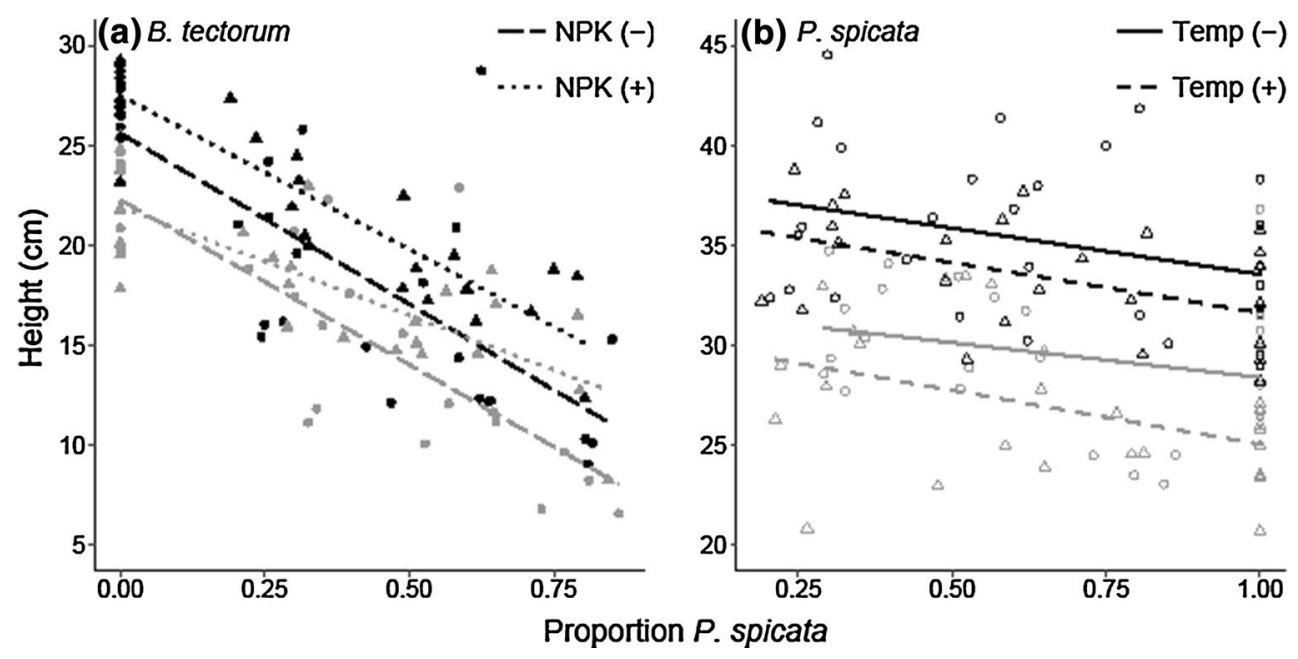

Fig. 2 Height response under ambient and decreased water (black and gray, respectfully) for a Bromus tectorum in ambient (long dashed line, solid circles) and elevated (dotted line, solid triangles) nutrients and b Pseudoroegneria spicata in ambient (solid line, open circle) and elevated (short dash line, open triangles) temperature. Mixed-effects models demonstrated: a B. tectorum height was nega-

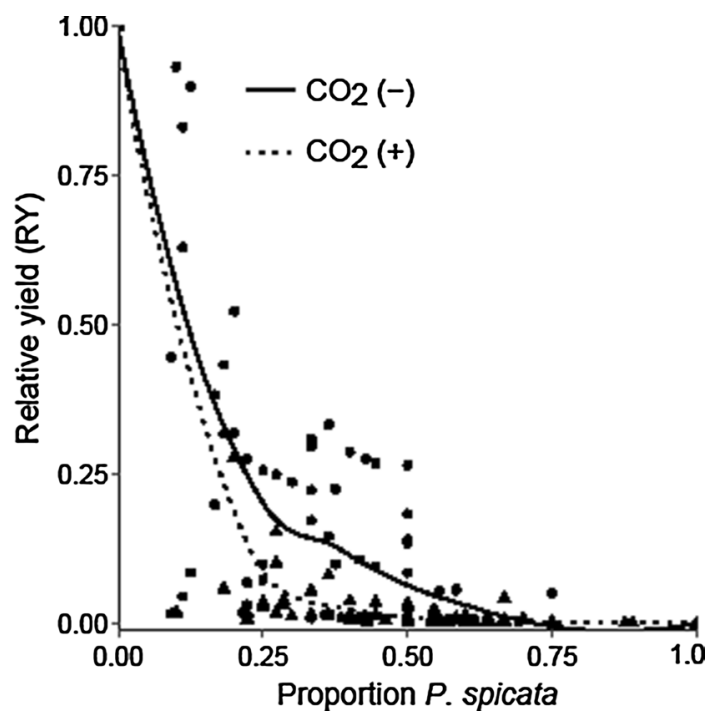

Fig. 3 Bromus tectorum relative yield in the ambient (solid line, solid circles) and elevated (dotted line, solid triangles) atmospheric $\mathrm{CO}_{2}$ treatments. A mixed-effects model demonstrated that elevated $\mathrm{CO}_{2}(n=139)$ and competition with $P$. spicata $(n=139)$ had negative effects on $B$. tectorum relative yield $(P<0.001$ and $P<0.001$, respectively)

height of $P$. spicata in the elevated $\mathrm{CO}_{2}$ monoculture treatment $(33.12 \mathrm{~cm})$ was taller than its mean height in the ambient $\mathrm{CO}_{2}$ monoculture treatment. $(22.66 \mathrm{~cm} ; P<0.001, t$ statistic $=10.23, d f=44)$.

Pseudoroegneria spicata pot proportion negatively and positively affected the $B$. tectorum and P. spicata relative tively affected by $P$. spicata pot proportion $(n=106, P<0.001)$ and decreased water $(n=106, P<0.001)$, while it responded positively to increased nutrients $(n=64, P<0.001)$; b $P$. spicata height was negatively affected by $P$. spicata pot proportion $(n=106, P<0.001)$, increased temperature $(n=106, P<0.001)$, and decreased water $(n=106, P<0.001)$

contributions to total pot biomass, respectively $(P<0.001)$. Likewise, the response of the proportion pot biomass to the elevated $\mathrm{CO}_{2}$ treatment demonstrated the same trend $(P<0.001$; Table 2$)$. The water treatment did not affect the species proportion of the total pot biomass $(P=0.428$; Table 2).

\section{Discussion}

Established native perennial grasses, including $P$. spicata, are highly competitive with B. tectorum (Orloff et al. 2013; Prevéy and Seastedt 2015; Larson et al. 2017) and are the most significant biotic factor limiting $B$. tectorum distribution in the sagebrush biome (Brummer et al. 2016). Consistent with the literature and as expected, in both of our experiments and under all conditions, interspecific competition with established $P$. spicata individuals was the most significant factor limiting $B$. tectorum growth.

Bromus tectorum biomass and fecundity can respond positively to experimental warming in competitive community settings (Zelikova et al. 2013; Compagnoni and Adler 2014a, b; Blumenthal et al. 2016). However, B. tectorum cover, density, and fecundity have also been found to respond negatively to experimental warming when in a competitive community setting (Larson et al. 2017). Interestingly, our results were consistent with both sets of studies: B. tectorum individual metrics (height and biomass) failed to respond to our elevated temperature treatment, while B. tectorum relative yield, which accounts for the 
Table 3 Results of the linear mixed-effects models assessing the effects of experimental treatments on B. tectorum and P. spicata aboveground biomass $(\mathrm{g})$, height $(\mathrm{cm})$, and relative yield $(\mathrm{RY})$, for the second experiment. Experimental treatments were: competition with Pseudoroegneria spicata, elevated atmospheric $\mathrm{CO}_{2}, \mathrm{CO}_{2}(+)$, and decreased water, water $(-)$

\begin{tabular}{|c|c|c|c|c|c|c|c|c|}
\hline \multicolumn{7}{|l|}{ Fixed effects } & \multirow{2}{*}{\multicolumn{2}{|c|}{$\frac{\text { Random effects }}{\text { Variance }}$}} \\
\hline \multirow[t]{2}{*}{ Response } & \multirow[t]{2}{*}{ Predictor } & \multirow[t]{2}{*}{ Est. } & \multirow[t]{2}{*}{ SE } & \multirow[t]{2}{*}{$d f$} & \multirow[t]{2}{*}{$t$ value } & \multirow[t]{2}{*}{$P(>)$} & & \\
\hline & & & & & & & Trial & Residual \\
\hline \multicolumn{9}{|l|}{ B. tectorum } \\
\hline \multirow[t]{6}{*}{ Biomass (g) } & Intercept & -0.38 & 0.51 & 1.06 & -0.74 & 0.587 & $0.49 \pm 0.70$ & $0.69 \pm 0.83$ \\
\hline & $\mathrm{CO}_{2}(+)$ & -0.31 & 0.12 & 178.00 & -2.53 & 0.012 & & \\
\hline & Water $(-)$ & -0.30 & 0.12 & 178.00 & -2.47 & 0.014 & & \\
\hline & P. spicata & -15.55 & 1.30 & 178.07 & -11.97 & $<0.001$ & & \\
\hline & P. spicata ${ }^{2}$ & 3.74 & 0.12 & 178.07 & 2.60 & 0.010 & & \\
\hline & P. spicata $\times \mathrm{CO}_{2}(+)$ & -7.33 & 1.73 & 178.03 & -4.24 & $<0.001$ & & \\
\hline \multirow[t]{5}{*}{ Height $(\mathrm{cm})$} & Intercept & 2.60 & 0.26 & 1.03 & 9.88 & 0.060 & $0.13 \pm 0.37$ & $0.10 \pm 0.31$ \\
\hline & $\mathrm{CO}_{2}(+)$ & -0.09 & 0.05 & 177.00 & -1.97 & 0.050 & & \\
\hline & Water $(-)$ & -0.08 & 0.05 & 177.00 & -1.73 & 0.086 & & \\
\hline & P. spicata & -3.55 & 0.47 & 177.02 & -7.51 & $<0.001$ & & \\
\hline & P. spicata $\times \mathrm{CO}_{2}(+)$ & -1.96 & 0.64 & 177.01 & -3.07 & 0.002 & & \\
\hline \multirow[t]{4}{*}{ Relative yield (RY) } & Intercept & -2.98 & 0.96 & 1.03 & -3.10 & 0.193 & $1.80 \pm 1.34$ & $0.86 \pm 0.92$ \\
\hline & $\mathrm{CO}_{2}(+)$ & -1.52 & 0.16 & 134.00 & -9.39 & $<0.001$ & & \\
\hline & Water $(-)$ & 0.15 & 0.16 & 134.00 & 0.96 & 0.339 & & \\
\hline & P. spicata & -12.65 & 0.96 & 134.02 & -13.20 & $<0.001$ & & \\
\hline \multicolumn{9}{|l|}{ P. spicata } \\
\hline \multirow[t]{7}{*}{ Biomass (g) } & Intercept & 1.38 & 0.38 & 1.01 & 3.60 & 0.170 & $0.29 \pm 0.54$ & $0.08 \pm 0.28$ \\
\hline & $\mathrm{CO}_{2}(+)$ & 0.57 & 0.04 & 178.00 & 13.48 & $<0.001$ & & \\
\hline & Water $(-)$ & -0.23 & 0.04 & 178.00 & -5.62 & $<0.001$ & & \\
\hline & P. spicata & 2.88 & 0.39 & 178.00 & 7.41 & $<0.001$ & & \\
\hline & P. spicata ${ }^{2}$ & -1.87 & 0.39 & 178.01 & -4.85 & $<0.001$ & & \\
\hline & P. spicata $\times \mathrm{CO}_{2}(+)$ & -2.32 & 0.58 & 178.00 & -3.98 & $<0.001$ & & \\
\hline & P. spicata ${ }^{2} \times \mathrm{CO}_{2}(+)$ & 1.59 & 0.59 & 178.00 & 2.70 & 0.008 & & \\
\hline \multirow[t]{5}{*}{ Height (cm) } & Intercept & 24.47 & 2.17 & 1.07 & 11.27 & 0.048 & $8.95 \pm 3.00$ & $14.54 \pm 3.81$ \\
\hline & $\mathrm{CO}_{2}(+)$ & 10.52 & 0.56 & 181.00 & 18.71 & $<0.001$ & & \\
\hline & Water $(-)$ & -2.17 & 0.56 & 181.00 & -3.89 & $<0.001$ & & \\
\hline & P. spicata & 5.86 & 5.22 & 181.03 & 1.12 & 0.263 & & \\
\hline & P. spicata $\times \mathrm{CO}_{2}(+)$ & -28.16 & 7.72 & 181.02 & -3.65 & $<0.001$ & & \\
\hline \multirow[t]{6}{*}{ Relative yield (RY) } & Intercept & 0.57 & 0.02 & 8.62 & 33.80 & $<0.001$ & $<0.001 \pm 0.008$ & $0.009 \pm 0.09$ \\
\hline & $\mathrm{CO}_{2}(+)$ & 0.03 & 0.02 & 132.00 & 1.198 & 0.233 & & \\
\hline & Water $(-)$ & -0.07 & 0.02 & 132.01 & -3.33 & 0.001 & & \\
\hline & P. spicata & 1.90 & 0.10 & 132.00 & 19.72 & $<0.001$ & & \\
\hline & P. spicata $^{2}$ & -0.51 & 0.09 & 132.45 & -5.50 & $<0.001$ & & \\
\hline & $\mathrm{CO}_{2}(+) \times$ Water $(-)$ & 0.10 & 0.03 & 132.02 & 3.43 & $<0.001$ & & \\
\hline
\end{tabular}

Response variables were assessed in pots with $0.1 \mathrm{~m}^{-2}$ area. Random effects are the mean trial and residual variance and the associated standard deviation

effects of interspecific competition, responded positively to warmer temperatures. The latter response is likely due to $P$. spicata's substantial negative response to the experimental warming and demonstrates an apparent increase in B. tectorum competitiveness under these conditions. As experimental warming can negatively affect bunchgrass ecosystems (Carlyle et al. 2014), and P. spicata has demonstrated a limited ability to adapt to altered climate conditions (Fraser et al. 2009), the P. spicata negative responses and $B$. tectorum's competitiveness under warmer conditions were expected and support our first hypothesis. Pseudoroegneria spicata relative yield did demonstrate an interaction between temperature and water availability; however, when compared to the reference level (ambient 


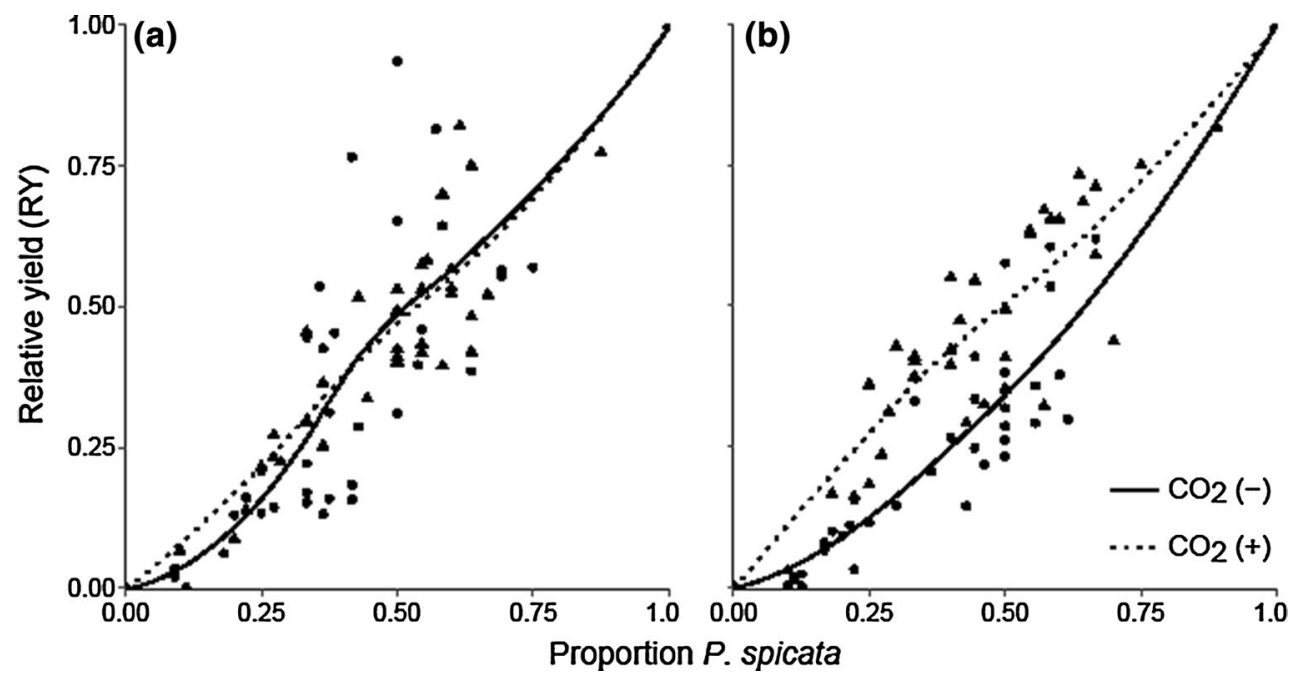

Fig. 4 Pseudoroegneria spicata relative yield response in a ambient and $\mathbf{b}$ decreased water treatments to ambient (solid line, solid circles) and elevated (dotted line, solid triangles) atmospheric $\mathrm{CO}_{2}$. A mixedeffects model demonstrated that $P$. spicata pot proportion $(n=139$, $P<0.001)$ positively affected $P$. spicata relative yield and elevated $\mathrm{CO}_{2}$ had no effect $(n=139, P=0.233)$, while decreased water avail-

water, ambient temperature), the effects of the interaction were still negative.

Bromus tectorum and P. spicata respond negatively to decreased water availability (Cline et al. 1977; Chambers et al. 2007; Fraser et al. 2009; Prevéy and Seastedt 2015; Larson et al. 2017). Consistent with these findings, we found that individually, both species responded negatively to the lower water treatment. However, B. tectorum's shallow diffuse root structure lends it a greater ability to extract water from extremely dry soil, which increases its competitiveness with its native perennial neighbors when water is limiting (Harris 1967; Eissenstat and Caldwell 1988; Link et al. 1990). The specific proportion of the total biomass results, a metric used to evaluate the competition between the two species, demonstrated B. tectorum's competitiveness in dry conditions. These results, in addition to $P$. spicata's individual negative responses to both the warming and drying treatments, support our hypothesis that increased temperature and decreased water alter the competitive dynamics in favor of the invasive B. tectorum. One of the limitations of our study was that, being a growth chamber study, we were only able to decrease the quantity of soil water and could not address the importance of the seasonality of soil moisture availability (Prevéy and Seastedt 2015; Larson et al. 2017).

Studies have found that non-native invasive plant species outcompete native plants in high resource environments, while native plants are more successful in low resource areas (Davis et al. 2000; Daehler 2003; though see Maron and Marler 2008). Bromus tectorum is associated with areas where elevated nutrients are present (Norton et al. 2004), ability had a negative effect $(n=139, P=0.001)$. There was a significant interaction between the $\mathrm{CO}_{2}$ and water treatments $(P<0.001)$ : $P$. spicata relative yield demonstrated no response to elevated $\mathrm{CO}_{2}$ in the a ambient water treatment and a positive response in the $\mathbf{b}$ decreased water treatment

and it is a very strong competitor for available soil nutrients, especially nitrogen (Booth et al. 2003); thus, its successful invasion and response to fire have been tied to increased availability of soil nutrients (D'Antonio and Vitousek 1992; Vasquez et al. 2008; He et al. 2011; Orloff et al. 2013). Consistent with the literature, the addition of nutrients had positive effects on all B. tectorum response variables (biomass, height, and relative yield) in our first experiment. Similarly, the addition of nutrients combined with the decreased water treatment increased the $B$. tectorum proportion of the total pot biomass and increased RYT, indicating a decrease in competitive interference by $P$. spicata. There was generally a lack of response by $P$. spicata to the nutrient addition. Consistent with our hypothesis, this suggests that, while interspecific competition with the larger P. spicata still limited B. tectorum, added nutrients did increase $B$. tectorum's competitiveness, decreased $P$. spicata's competitive interference, and drier conditions exaggerated this effect.

Elevated $\mathrm{CO}_{2}$ concentrations have consistently been associated with increased growth, especially for $\mathrm{C} 3$ species (Bazzaz 1990; Poorter 1993; Ackerly and Bazzaz 1995; Polley 1997; Poorter and Navas 2003) including B. tectorum (Smith et al. 1987; Poorter 1993; Ziska et al. 2005). A mechanism through which atmospheric $\mathrm{CO}_{2}$ concentrations facilitate plant growth is by increasing plant water use efficiency (Bazzaz 1990); therefore, soil water relations will mediate and affect how plant communities respond to increasing $\mathrm{CO}_{2}$ (Bazzaz et al. 1992; Morgan et al. 2004; Smith et al. 2014). A long-term free-air carbon dioxide enrichment (FACE) plant community study (Smith et al. 2014) demonstrated 
the importance of this interaction for annual grasses. Smith et al. (2014) demonstrated that responses by an annual Bromus spp. to elevated $\mathrm{CO}_{2}$ were highly contingent on soil moisture. Thus, the second goal of our study was to assess the impact of elevated atmospheric $\mathrm{CO}_{2}$ concentrations on the competition between $P$. spicata and B. tectorum and to determine if these effects were responsive to a $50 \%$ reduction in water availability.

Consistent with the results of the other B. tectorum $\mathrm{CO}_{2}$-controlled setting studies (Smith et al. 1987; Ziska et al. 2005) when B. tectorum and P. spicata, were grown in monoculture, elevated $\mathrm{CO}_{2}$ had positive effects. However, when grown in competition, our findings were inconsistent with these findings and those of the only relevant field experiment, which found $B$. tectorum responded neutrally to elevated $\mathrm{CO}_{2}$ in a native Wyoming mixed prairie community (Blumenthal et al. 2016). We found that the individual metrics (height, biomass) of the established $P$. spicata responded positively to elevated $\mathrm{CO}_{2}$, while the same metrics of the younger $B$. tectorum plants responded negatively. Furthermore, the effective changes in the specific proportion of total pot biomass and relative yield clearly demonstrated that elevated $\mathrm{CO}_{2}$ provided the established $P$. spicata with an even greater competitive edge. The decreased water treatment had no effect on $B$. tectorum's response to elevated $\mathrm{CO}_{2}$ and it was clear that when soil moisture was reduced, a condition which has previously been shown to favor $B$. tectorum, $P$. spicata greatly benefitted from the elevated $\mathrm{CO}_{2}$ concentration.

Resource availability and the presence of neighbors influence competitive and community responses to elevated $\mathrm{CO}_{2}$; therefore, they often differ significantly from monoculture responses (Ackerly and Bazzaz 1995; Shaw et al. 2002; Smith et al. 2014). There are two likely mechanisms underlying $B$. tectorum's response to elevated $\mathrm{CO}_{2}$. First, B. tectorum is strongly limited by interspecific competition with established $P$. spicata (Orloff et al. 2013) and the elevated $\mathrm{CO}_{2}$ enhanced the size and competitive advantage, especially for light, of the established P. spicata individuals; thus, the effects of increased interspecific competition overwhelmed any positive effects the increased $\mathrm{CO}_{2}$ had on $B$. tectorum. The second mechanism potentially underlying $B$. tectorum's response to elevated $\mathrm{CO}_{2}$ while in competition could be the indirect effects of the $\mathrm{CO}_{2}$ on available N. Elevated $\mathrm{CO}_{2}$ commonly reduces $\mathrm{N}$ availability (Luo et al. 2004), which could moderate the positive effects that elevated $\mathrm{CO}_{2}$ might hold for invasive species (Sorte et al. 2013; Blumenthal et al. 2016), especially those that are responsive to heightened nutrient availability, such as $B$. tectorum. Additionally, $B$. tectorum's response could be the result of an interaction between the two mechanisms: the larger P. spicata used more soil nutrients, thereby causing soil nutrient limitation for the smaller, less competitive, B. tectorum.
Bromus tectorum is highly competitive with native perennial grasses when moisture is limiting (Harris 1967; Eissenstat and Caldwell 1988). However, we found in elevated $\mathrm{CO}_{2}$ that $P$. spicata experienced less competition with $B$. tectorum in dry conditions. One potential explanation for this result is an improvement of $P$. spicata water use efficiency under these conditions, and is a common effect that elevated $\mathrm{CO}_{2}$ can have on $\mathrm{C}_{3}$ species (Bazzaz 1990). Another potential explanation is that the larger $P$. spicata individuals had larger root systems and, thus, obtained a greater amount of the limiting resource than the smaller $B$. tectorum individuals. Such a response by one of $B$. tectorum's perennial bunchgrass competitors could limit invasion success of $B$. tectorum under future climate conditions and $\mathrm{CO}_{2}$ concentrations.

The sagebrush-steppe biome in the western USA is projected to become warmer with more variable precipitation, and with more frequent wildfires (Chambers and Pellant 2008; Bradley 2009; Mote and Salathé 2010; Westerling et al. 2011); thus, it has been postulated $B$. tectorum's range will expand (Bradley 2009; Taylor et al. 2014; Bradley et al. 2016). Furthermore, elevated atmospheric $\mathrm{CO}_{2}$ concentrations are expected to favor invasive species (Dukes and Mooney 1999; Weltzin et al. 2003; Ziska and George 2004; Thuiller et al. 2008), including B. tectorum (Smith et al. 1987; Ziska et al. 2005). Our findings demonstrate that recently established $P$. spicata significantly suppresses $B$. tectorum, especially in elevated atmospheric $\mathrm{CO}_{2}$. Furthermore, despite B. tectorum experiencing an increase in competitiveness under decreased water, increased temperature, and elevated nutrient conditions, this suppressive effect was still the most significant factor affecting $B$. tectorum growth. Being conducted in a greenhouse under controlled settings, our study has limitations; specifically, we were unable to address the phenological differences of the species and the seasonality of the water availability, which are important for competition between these species. Thus, our study can only provide limited evidence that global climate change is unlikely to facilitate the spread of $B$. tectorum dominance into those sagebrush-steppe communities with an undisturbed perennial bunchgrass component. However, the positive effects that elevated temperatures, reduced water availability, and elevated nutrients had on B. tectorum's competitiveness, in addition to its positive response to $\mathrm{CO}_{2}$ when grown without interspecific competition, demonstrate the importance of limiting human-caused disturbance and maintaining intact native sagebrush-steppe communities.

Acknowledgements We would like to thank Noelani Boise for her assistance with this Project. CN was supported by Montana State University Undergraduate Scholars Program. LJR and CDL were supported by the United States Department of Agriculture, National Institute of Food and Agriculture, Hatch Project MONB00363. EAL was 
supported by the United States Department of Agriculture, National Institute of Food and Agriculture, Hatch Project NMLehnhoff-17H.

Author contribution statement CDL, EAL, CN, and LJR originally formulated the idea and developed the methodology, CDL and CN collected the data, CDL performed the statistical analyses with assistance from LJR, and CDL wrote the manuscript with contributions from LJR and EAL.

Open Access This article is distributed under the terms of the Creative Commons Attribution 4.0 International License (http://creativecomm ons.org/licenses/by/4.0/), which permits unrestricted use, distribution, and reproduction in any medium, provided you give appropriate credit to the original author(s) and the source, provide a link to the Creative Commons license, and indicate if changes were made.

\section{References}

Ackerly DD, Bazzaz FA (1995) Plant growth and reproduction along $\mathrm{CO}_{2}$ gradients: non-linear responses and implications for community change. Glob Chang Biol 1:199-207. https://doi.org/10.1111 /j.1365-2486.1995.tb00021.x

Alward RD, Detling JK, Milchunas DG (1999) Grassland vegetation changes and nocturnal global warming. Science 283:229-231. https://doi.org/10.1126/science.283.5399.229

Bates D, Maechler M, Bolker B (2011) lme4: linear mixed-effects models using S4 classes. R package version 0.999999-2. http://lme4 .r-forge.r-project.org/. Accessed 29 Aug 2016

Bazzaz FA (1990) The response of natural ecosystems to the rising global $\mathrm{CO}_{2}$ levels. Annu Rev Ecol Syst 21:167-196. https://doi. org/10.1146/annurev.es.21.110190.001123

Bazzaz FA, Ackerly DD, Woodward FI, Rochefort L (1992) $\mathrm{CO}_{2}$ enrichment and dependence of reproduction on density in an annual plant and a simulation of its population dynamics. J Ecol 80:643-651. https://doi.org/10.2307/2260856

Betts RA, Jones CD, Knight JR, Keeling RF, Kennedy JJ (2016) El Niño and a record $\mathrm{CO}_{2}$ rise. Nat Clim Chang 6:806-810. https:// doi.org/10.1038/NCLIMATE3063

Blank RR, Chambers JC, Roundy B, Whittaker A (2007) Nutrient availability in rangeland soils: influence of prescribed burning, herbaceous vegetation removal, overseeding with Bromus tectorum, season, and elevation. Rangel Ecol Manag 60:644-655. http s://doi.org/10.2458/azu_jrm_v60i6_blank

Blumenthal DM, Kray JA, Ortmans W, Ziska LH, Pendall E (2016) Cheatgrass is favored by warming but not $\mathrm{CO}_{2}$ enrichment in a semi-arid grassland. Glob Chang Biol 22:3026-3038. https://doi. org/10.1111/gcb.13278

Booth MS, Caldwell MM, Stark JM (2003) Overlapping resource use in three Great Basin species: implications for community invasibility and vegetation. J Ecol 91:36-48. https://doi.org/10.1046/j.1365 $-2745.2003 .00739 . x$

Bradley BA (2009) Regional analysis of the impacts of climate change on cheatgrass invasion shows potential risk and opportunity. Glob Chang Biol 15:196-208. https://doi.org/10.1111/j.1365-2486 .2008.01709.x

Bradley BA, Curtis CA, Chambers JC (2016) Bromus response to climate and Projected changes with climate change. In: Germino MJ, Chambers JC, Brown CS (eds) Exotic brome-grasses in arid and semiarid ecosystems of the western US. Springer International Publishing, New York, pp 257-274
Brummer TJ, Taylor KT, Rotella J, Maxwell BD, Rew LJ, Lavin M (2016) Drivers of Bromus tectorum abundance in the western North American sagebrush steppe. Ecosystems 19:986-1000. http s://doi.org/10.1007/s10021-016-9980-3

Burnett SA, Mealor BA (2015) Imazapic effects on competition dynamics between native perennial grasses and downy brome (Bromus tectorum). Invasive Plant Sci Manag 8:72-80. https:// doi.org/10.1614/IPSM-D-14-00032.1

Carlyle CN, Fraser LH, Turkington R (2014) Response of grassland biomass production to simulated climate change and clipping along an elevation gradient. Oecologia 174:1065-1073. https:// doi.org/10.1007/s00442-013-2833-2

Chambers JC, Pellant M (2008) Climate change impacts on Northwestern and Intermountain United States rangelands. Rangelands 30:29-33. https://doi.org/10.2111/1551-501X(2008)30[29:CCIO $\mathrm{NA}] 2.0 . \mathrm{CO} ; 2$

Chambers JC, Roundy BA, Blank RR, Meyer SE, Whittaker A (2007) What makes Great Basin sagebrush ecosystems invasible by Bromus tectorum? Ecol Monogr 77:117-145. https://doi.org/10.1890 /05-1991

Chambers JC, Bradley BA, Brown CS, D’Antonio C, Germino MJ, Grace JB, Hardegree SP, Miller RF, Pyke DA (2014) Resilience to stress and disturbance, and resistance to Bromus tectorum L. invasion in cold desert shrublands of western North America. Ecosystems 17:360-375. https://doi.org/10.1007/s10021-013-9725-5

Chen I, Hill JK, Ohlemüller R, Roy DB, Thomas CD (2011) Rapid range shifts of species associated with high levels of climate warming. Science 333:1024-1026. https://doi.org/10.1126/scie nce. 1206432

Cline JF, Uresk DW, Rickard WH (1977) Comparison of soil water used by a sagebrush-bunchgrass and a cheatgrass community. J Range Manag 30:199-201. https://doi.org/10.2307/3897469

Compagnoni A, Adler PB (2014a) Warming, competition, and Bromus tectorum population growth across an elevation gradient. Ecosphere 5:1-18. https://doi.org/10.1890/es14-00047.1

Compagnoni A, Adler PB (2014b) Warming, soil moisture, and loss of snow increase Bromus tectorum's population growth rate. Elem Sci Anthr 2:1-10. https://doi.org/10.12952/journal.elementa.0000 20

Cousens R, Neill MO (1993) Density dependence of replacement series experiments. Oikos 66:347-352. https://doi.org/10.2307/3544824

Cramer W, Bondeau A, Woodward FI, Prentice IC, Betts RA, Brovkin V, Cox PM, Fisher V, Foley JA, Friend AD, Kucharik C, Lomas MR, Ramankutty N, Sitch S, Smith B, White A, Young-Molling C (2001) Global response of terrestrial ecosystem structure and function to $\mathrm{CO}_{2}$ and climate change: results from six dynamic global vegetation models. Glob Chang Biol 7:357-373. https:// doi.org/10.1046/j.1365-2486.2001.00383.x

D'Antonio CM, Vitousek PM (1992) Biological invasions by exotic grasses, the grass fire cycle, and global change. Annu Rev Ecol Syst 23:63-87. https://doi.org/10.1146/annurev.ecolsys.23.1.63

Daehler CC (2003) Performance comparisons of co-occurring native and alien invasive plants: implications for conservation and restoration. Annu Rev Ecol Evol Syst 34:183-211. https://doi. org/10.1146/132403

Davis MA, Grime JP, Thompson K (2000) Fluctuating resources in plant communities: a general theory of invasibility. J Ecol 88:528534. https://doi.org/10.1046/j.1365-2745.2000.00473.x

Dermody O, Weltzin JF, Engel EC, Allen P, Norby RJ (2007) How do elevated $\left[\mathrm{CO}_{2}\right]$, warming, and reduced precipitation interact to affect soil moisture and LAI in an old field ecosystem? Plant Soil 301:255-266. https://doi.org/10.1007/s11104-007-9443-x

Dodson EK, Root HT (2015) Native and exotic plant cover vary inversely along a climate gradient 11 years following stand-replacing wildfire in a dry coniferous forest, Oregon, USA. Glob Chang Biol 21:666-675. https://doi.org/10.1111/gcb.12775 
Dukes JS (2000) Will the increasing atmospheric $\mathrm{CO}_{2}$ concentration affect the success of invasive species. In: Mooney HA, Hobbs RJ (eds) Invasive species in a Changing World. Island Press, Washington, DC, pp 95-113

Dukes JS (2002) Comparison of the effect of elevated $\mathrm{CO}_{2}$ on an invasive species (Centaurea solstitialis) in monoculture and community settings. Plant Ecol 160:225-234. https://doi.org/10.1023 /A: 1015813919850

Dukes JS, Mooney HA (1999) Does global change increase the success of biological invaders? Trends Ecol Evol 14:135-139. https://doi. org/10.1016/S0169-5347(98)01554-7

Dukes JS, Chiariello NR, Loarie SR, Field CB (2011) Strong response of an invasive plant species (Centaurea solstitialis L.) to global environmental changes. Ecol Appl 21:1887-1894. https://doi. org/10.1890/11-0111.1

Eissenstat DM, Caldwell MM (1988) Competitive ability is linked to rates of water extraction: a field study of two aridland tussock grasses. Oecologia 75:1-7. https://doi.org/10.1007/BF00378806

Everard K, Seabloom EW, Harpole S, de Mazancourt C (2010) Plant water use affects competition for nitrogen: why drought favors invasive species in California. Am Nat 175:85-97. https://doi. org/10.1086/648557

Fraser LH, Greenall A, Carlyle C, Turkington R, Ross Friedman C (2009) Adaptive phenotypic plasticity of Pseudoroegneria spicata: response of stomatal density, leaf area and biomass to changes in water supply and increased temperature. Ann Bot 103:769-775. https://doi.org/10.1093/aob/mcn252

Harris GA (1967) Some competitive relationships between Agropyron spicatum and Bromus tectorum. Ecol Monogr 37:89-111. https:// doi.org/10.2307/2937337

He WM, Yu GL, Sun ZK (2011) Nitrogen deposition enhances Bromus tectorum invasion: biogeographic differences in growth and competitive ability between China and North America. Ecography (Cop) 34:1059-1066. https://doi.org/10.1111/j.1600-0587.2011 .06835.x

Hobbs RJ, Huenneke LF (1992) Disturbance, diversity, and invasion: implications for conservation. Conserv Biol 6:324-337. https:// doi.org/10.1046/j.1523-1739.1992.06030324.x

Hoeppner SS, Dukes JS (2012) Interactive responses of old-field plant growth and composition to warming and precipitation. Glob Chang Biol 18:1754-1768. https://doi.org/10.1111/j.1365-2486 .2011.02626.x

IPCC (2013) Summary for Policymakers. In: Stocker TF, Qin D, Plattner G-K, Tignor M, Allen SK, Boschung J, Nauels A, Xia Y, Bex V, Midgley PM (eds) Climate change 2013: the physical science basis. Contribution of Working Group I to the Fifth Assessment Report of the Intergovernmental Panel on Climate Change. Cambridge University Press, Cambridge, New York

Knapp PA (1996) Cheatgrass (Bromus tectorum L.) dominance in the Great Basin Desert. Glob Environ Chang 6:37-52. https://doi. org/10.1016/0959-3780(95)00112-3

Kuznetsova A, Brockhoff PB, Christensen RHB (2014). lmerTest: tests in linear mixed effects models. R package version 2.0-20. http:// CRAN.R-project.org/package=lmerTest. Accessed 20 Oct 2016

Larson CD, Lehnhoff EA, Rew LJ (2017) A warmer and drier climate in the northern sagebrush biome does not promote cheatgrass invasion or change its response to fire. Oecologia 185:763-774. https://doi.org/10.1007/s00442-017-3976-3

Lenoir J, Svenning JC (2015) Climate-related range shifts-a global multidimensional synthesis and new research directions. Ecography 37:1-14. https://doi.org/10.1111/ecog.00967

Link SO, Gee GW, Downs JL (1990) The effect of water stress on phenological and ecophysiological characteristics of cheatgrass and Sandberg' s bluegrass. J Range Manag 43:506-513. https:// doi.org/10.2307/4002354
Luo Y, Su B, Currie WS, Dukes JS, Finzi A, Hartwig U, Hungate B, McMurtrie RE, Oren R, Parton WJ, Pataki DE, Shaw MR, Zak DR, Field CB (2004) Progressive nitrogen limitation of ecosystem responses to rising atmospheric carbon dioxide. Bioscience 54:731-739. https://doi. org/10.1641/0006-3568(2004)054[0731:PNLOER]2.0.CO;2

Mack RN (1981) Invasion of Bromus tectorum L. into western North America: an ecological chronicle. Agro-ecosystems 7:145-165. https://doi.org/10.1016/0304-3746(81)90027-5

Manea A, Leishman MR (2011) Competitive interactions between native and invasive exotic plant species are altered under elevated carbon dioxide. Oecologia 165:735-744. https://doi.org/10.1007 /s00442-010-1765-3

Maron JL, Marler M (2008) Field-based competitive impacts between invaders and natives at varying resource supply. J Ecol 96:11871197. https://doi.org/10.1111/j.1365-2745.2008.01440.x

Milchunas DG, Lauenroth WK (1995) Inertia in plant community structure: state changes after cessation of nutrient-enrichment stress. Ecol Appl 5:452-458. https://doi.org/10.2307/1942035

Moore PD (2004) Plant ecology: favoured aliens for the future. Nature 427:594. https://doi.org/10.1038/427594a

Morgan JA, Pataki DE, Körner C, Clark H, Del Grosso SJ, Grünzweig JM, Ak Knapp, Mosier AR, Newton PCD, Niklaus PA, Nippert JB, Nowak RS, Parton WJ, Polley HW, Shaw MR (2004) Water relations in grassland and desert ecosystems exposed to elevated atmospheric $\mathrm{CO}_{2}$. Oecologia 140:11-25. https://doi.org/10.1007 /s00442-004-1550-2

Mote PW, Salathé EP (2010) Future climate in the Pacific Northwest. Clim Change 102:29-50. https://doi.org/10.1007/s10584-0109848-Z

Norton JB, Monaco TA, Norton JM, Johnson DA, Jones TA (2004) Soil morphology and organic matter dynamics under cheatgrass and sagebrush-steppe plant communities. J Arid Environ 57:445-466. https://doi.org/10.1016/S0140-1963(03)00104-6

Orloff LN, Mangold JM, Menalled FD (2013) Role of size and nitrogen in competition between annual and perennial grasses. Invasive Plant Sci Manag 6:87-98. https://doi.org/10.1614/IPSM-D-1200035.1

Parmesan C, Yohe G (2003) A globally coherent fingerprint of climate change impacts across natural systems. Nature 421:37-42. https:// doi.org/10.1038/nature01286

Polley HW (1997) Implications of rising atmospheric carbon dioxide concentration for rangelands. J Range Manag 50:562-577. https:// doi.org/10.2307/4003450

Poorter H (1993) Interspecific variation in the growth response of plants to an elevated ambient $\mathrm{CO}_{2}$ concentration. Vegetatio 104(105):76-97. https://doi.org/10.1007/BF00048146

Poorter H, Navas M-L (2003) Plant growth and competition at elevated $\mathrm{CO}_{2}$ : on winners, losers and functional groups. New Phytol 157:175-198. https://doi.org/10.1046/j.1469-8137.2003.00680.x

Prevéy JS, Seastedt TR (2014) Seasonality of precipitation interacts with exotic species to alter composition and phenology of a semiarid grassland. J Ecol 102:1549-1561. https://doi.org/10.1111 /1365-2745.12320

Prevéy JS, Seastedt TR (2015) Effects of precipitation change and neighboring plants on population dynamics of Bromus tectorum. Oecologia 179:765-775. https://doi.org/10.1007/s00442-0153398-z

R Development Core Team (2015) R: A language and environment for statistical computing. 3.2.2 edn. R Foundation for Statistical Computing, Vienna, Austria

Shaver GR, Canadell F, Chapin FS, Gurevitch J, Harte J, Henry G, Ineson P, Jonasson S, Melillo J, Pitelka L, Rustad L (2000) Global warming and terrestrial ecosystems: a conceptual framework for analysis ecosystem responses to global warming will be complex and varied. Ecosystem warming experiments hold great potential 
for providing insights on ways terrestrial ecosystems will respond to upcoming decades of climate change. Documentation of initial conditions provides the context for understanding and predicting ecosystem responses. Bioscience 50:871-882. https://doi. org/10.1641/0006-3568(2000)050[0871:GWATEA]2.0.CO;2

Shaw MR, Zavaleta ES, Chiariello NR, Cleland EE, Mooney HA, Field CB (2002) Grassland responses to global environmental changes suppressed by elevated $\mathrm{CO}_{2}$. Science 298:1987-1990. https://doi. org/10.1126/science. 1075312

Smith SD, Strain BR, Sharkey TD (1987) Effects of $\mathrm{CO}_{2}$ enrichment on four Great Basin grasses. Funct Ecol 1:139-143. https://doi. org/10.2307/2389717

Smith SD, Charlet TN, Zitzer SF, Abella SR, Vanier CH, Huxman TE (2014) Long-term response of a Mojave Desert winter annual plant community to a whole-ecosystem atmospheric $\mathrm{CO}_{2}$ manipulation (FACE). Glob Chang Biol 20:879-892. https://doi. org/10.1111/gcb.12411

Sorte CJB, Ibáñez I, Blumenthal DM, Molinari NA, Miller LP, Grosholz ED, Diez JM, D'Antonio CM, Olden JD, Jones SJ, Dukes JS (2013) Poised to prosper? A cross-system comparison of climate change effects on native and non-native species performance. Ecol Lett 16:261-270. https://doi.org/10.1111/ele.12017

Suttle KB, Thomsen MA (2007) Climate change and grassland restoration in California: lessons from six years of rainfall manipulation in a north coast grassland. Madroño 54:225-233. https://doi. org/10.3120/0024-9637(2007)54[225:CCAGRI]2.0.CO;2

Taylor K, Potvin C (1997) Understanding the long-term effect of $\mathrm{CO}_{2}$ enrichment on a pasture: the importance of disturbance. Can J Bot 75:1621-1627. https://doi.org/10.1139/b97-874

Taylor K, Brummer T, Rew LJ, Lavin M, Maxwell BD (2014) Bromus tectorum response to fire varies with climate conditions. Ecosystems 17:960-973. https://doi.org/10.1007/s10021-014-9771-7

Thuiller W, Richardson DM, Midgley GF (2008) Will climate change promote alien plant invasions? In: Nentwig W (ed) Biological Invasions. Ecological studies (analysis and synthesis), vol 193. Springer, Berlin, Heidelberg

Vasquez E, Sheley R, Svejcar T (2008) Nitrogen enhances the competitive ability of cheatgrass (Bromus tectorum) relative to native grasses. Invasive Plant Sci Manag 1:287-295. https://doi. org/10.1614/IPSM-08-062.1
Walther G-R, Post E, Convey P, Menzel A, Parmesan C, Beebee TJC, Fromentin JM, Hoegh-Guldberg O, Bairlein F (2002) Ecological responses to recent climate change. Nature 416:389-395. https:// doi.org/10.1038/416389a

Wayne PM, Carnelli AL, Connolly J, Bazzaz FA (1999) The density dependence of plant responses to elevated $\mathrm{CO}_{2}$. J Ecol 87:183192. https://doi.org/10.1046/j.1365-2745.1999.00357.x

Weigelt A, Jolliffe P (2003) Indices of plant competition. J Ecol 91:707-720. https://doi.org/10.1046/j.1365-2745.2003.00805.x

Weltzin JF, Travis Belote R, Sanders NJ (2003) Biological invaders in a greenhouse world: will elevated $\mathrm{CO}_{2}$ fuel plant invasions? Front Ecol Environ 1:146-153. https://doi. org/10.1890/1540-9295(2003)001[0146:BIIAGW]2.0.CO;2

Westerling AL, Hidalgo HG, Cayan DR, Swetnam TW (2006) Warming and earlier spring increase western U.S. forest wildfire activity. Science 313:940-943. https://doi.org/10.1126/science.1128834

Westerling AL, Turner MG, Smithwick EAH, Romme WH, Ryan MG (2011) Continued warming could transform Greater Yellowstone fire regimes by mid-21st century. PNAS 108:13165-13170. http s://doi.org/10.1073/pnas.1110199108

Woodward FI, Williams BG (1987) Climate and plant distribution at global and local scales climate and plant distribution at global and local scales. Vegetatio 69:189-197. https://doi.org/10.1007 /BF00038700

Wu H, Ismail M, Ding J (2016) Global warming increases the interspecific competitiveness of the invasive plant alligator weed, Alternanthera philoxeroides. Sci Total Environ 575:1415-1422. http s://doi.org/10.1016/j.scitotenv.2016.09.226

Zelikova TJ, Hufbauer RA, Reed SC, Wertin T, Fettig C, Belnap J (2013) Eco-evolutionary responses of Bromus tectorum to climate change: implications for biological invasions. Ecol Evol 3:1374-1387. https://doi.org/10.1002/ece3.542

Ziska LH, George K (2004) Rising carbon dioxide and invasive, noxious plants: potential threats and consequences. World Resour Rev 16:427-447. https://doi.org/10.1007/s10584-010-9879-5

Ziska LH, Reeves JB III, Blank RR (2005) The impact of recent increases in atmospheric $\mathrm{CO}_{2}$ on biomass production and vegetative retention of Cheatgrass (Bromus tectorum): implications for fire disturbance. Glob Chang Biol 11:1325-1332. https://doi. org/10.1111/j.1365-2486.2005.00992.x 